\title{
DETERMINAN KEJADIAN KANKER PAYUDARA DI RSUD 45 KUNINGAN PERIODE TAHUN 2018-2019
}

\author{
${ }^{1}$ Evi Soviyati, ${ }^{2}$ Toto Sutarto Gani Utari, ${ }^{3}$ Putri Nabila \\ ${ }^{1}$ STIKes Kuningan, ${ }^{2}$ Universitas Pasundan, ${ }^{3}$ STIKes Kuningan \\ 1eviesofia73@gmail.com
}

\begin{abstract}
Abstrak
Kanker payudara merupakan ancaman bagi kaum wanita, dan merupakan peringkat kedua penyebab kematian perempuan. Laporan Rumah Sakit Dharmais, $70 \%$ wanita yang datang sudah dengan stadium lanjut, sisanya 30\% terdiagnosis pada stadium I atau II (pasien dalam usia 25-80 tahun). Tujuan penelitian adalah mengetahui determinan kejadian kanker payudara di Instalasi Rawat Inap Rumah Sakit Umum Daerah 45 Kuningan Periode Tahun 2018-2019. Jenis penelitian yang survey analitik dengan pendekatan survey case control, menggunakan data sekunder dengan jumlah total sampel 30 orang. Analisis data menggunakan Chi-Square. Hasil penelitian menunjukan bahwa dari ketiga faktor yang diteliti, terdapat dua faktor yang berhubungan dengan kasus kanker payudara, yaitu faktor umur dengan $p$ value 0,001 dan pendidikan dengan $p$ value 0,034. Sedangkan faktor riwayat keluarga dinilai tidak berhubungan karena memiliki $p$ value 0,767. Diharapkan lebih meningkatkan akses sumber informasi bagi para pendidik dan atau bidan. Hal ini bertujuan agar adanya perhatian yang lebih terhadap masalah kanker payudara sebagai salah satu penyebab faktor risiko kematian kanker tertinggi kedua pada wanita. Sehingga bisa direncanakan strategi-strategi untuk menurunkan angka kejadian kanker payudara dan komplikasi dari keadaan tersebut.
\end{abstract}

Kata Kunci: kanker payudara, faktor risiko.

\section{Pendahuluan}

Kanker payudara terjadi hampir seluruhnya pada wanita, tetapi pria bisa mendapatkannya juga. Kanker payudara dapat menyebar melalui sistem getah bening. Sistem getah bening termasuk kelenjar getah bening, pembuluh getah bening dan cairan getah bening. Kelenjar getah bening berbentuk kacang dan merupakan sistem kekebalan tubuh yang dihubungkan oleh getah bening (limfatik). Berdasarkan data dari Society, (2017), kanker payudara invasif didiagnosis sekitar 246.660 perempuan dan 2.600 laki-laki. Sebesar 61.000 kasus baru pada kanker 
JURNAL ILMU KESEHATAN BHAKTI HUSADA:

HEALTH SCIENCES JOURNAL, VOL. 11 NO. 01, JUNI 2020 DOI: 10.34305/jikbh.v11i1.140

payudara in situ didiagnosis pada wanita.

Perkiraan kanker payudara di Amerika Serikat untuk 2017 adalah 252.710 kasus baru kanker payudara invasif akan didiagnosis pada wanita dan 63.410 kasus baru carsinoma in situ (CIS) akan didiagnosis (CIS adalah non-invasif dan merupakan bentuk paling awal dari kanker payudara). Kanker payudara dimulai ketika sel-sel di payudara mulai tumbuh di luar kendali. Sel-sel ini biasanya membentuk tumor yang sering terlihat pada $x$-ray atau terasa sebagai benjolan. Sel-sel tumor ganas (kanker) dapat tumbuh menyerang jaringan atau menyebar (metastasis) ke daerah yang jauh disekitarnya. Prevalensi kanker payudara di Indonesia cukup tinggi. Menurut Kesehatan \& RI, (2013), prevalensi kanker di Indonesia adalah 1,4 dari 1.000 penduduk atau sekitar 347.000 orang. Di seluruh dunia 8,2 juta orang meninggal setiap tahun akibat kanker, meningkat dari sebelumnya 7,6 juta pada tahun 2008. Diperkirakan pada tahun 2025, jumlah orang meninggal dunia akibat kanker payudara meningkat menjadi 11,5 juta bila tidak dilakukan upaya pencegahan dan pengendalian yang efektif. Di Indonesia, kasus baru kanker payudara menjadi kasus kematian tertinggi dengan angka $21,5 \%$ pada setiap 100.000 , yang memprihatinkan $70 \%$ pasien kanker payudara baru datang ke fasilitas kesehatan pada stadium lanjut.
Ciptaan disebarluaskan di bawah

Lisensi Creative Commons Atribusi-

NonKomersial-BerbagiSerupa 4.0 Internasional.

Sedangkan di Jawa Barat setiap tahun kanker payudara dialami sekitar 1,2 juta wanita dengan angka kematian berkisar 500.000 orang. Sekitar 5\%-10\% penyebab kanker payudara adalah faktor yang diwariskan Kanker payudara merupakan suatu kondisi dimana sel telah kehilangan pengendalian dan mekanisme normalnya, sehingga terjadi pertumbuhan yang tidak normal, cepat dan tidak terkendali yang terjadi pada jaringan payudara (Mulyani, 2013)

Salah satu penyebab semakin berkembangnya kanker tersebut disebabkan oleh rendahnya cakupan deteksi dini atau screening. Sementara itu untuk meningkatkan pengetahuan dan pemahaman masyarakat dalam pencegahan dan penanggulangan kanker dilakukan melalui advokasi, sosialisasi termasuk komunikasi informasi dan edukasi (KIE). Untuk masyarakat meningkatkan perilaku hidup bersih dan sehat termasuk menghindari faktor resiko penyakit kanker seperti merokok atau terpajan asap rokok, mengkonsumsi makanan dengan gizi seimabang papar Menkes (Infodatin Kemenkes, 2015). 
JURNAL ILMU KESEHATAN BHAKTI HUSADA:

HEALTH SCIENCES JOURNAL, VOL. 11 NO. 01, JUNI 2020

DOI: $10.34305 /$ jikbh.v11i1.140
Ciptaan disebarluaskan di bawah Lisensi Creative Commons AtribusiNonKomersial-BerbagiSerupa 4.0 Internasional.

\section{Metode}

Jenis penelitian yang digunakan dalam penelitian ini adalah survey analitik. Rancangan yang digunakan dalam penelitian ini adalah rancangan survey case control. Populasi dalam penelitian ini adalah perempuan yang menderita penyakit kanker payudara yang pernah dirawat di Instalasi Rawat Inap Rumah Sakit Umum Daerah 45 Kuningan Tahun 2018/2019 sebanyak 30 orang. menggunakan teknik total sampling. Variabel bebas dalam penelitian ini terdiri dari umur, pendidikan, riwayat keluarga. Variabel terikat adalah kejadian kanker payudara. Instrumen dalam penelitian ini adalah menggunakan lembar

$(\sqrt{ })$ ceklist untuk mengumpulkan data dari rekam medik diantaranya mencatat nama, alamat, umur, riwayat keluarga dan kehamilan.Pengumpulan data dilakukan oleh peneliti sendiri di mana yang dikumpulkan berupa data sekunder. Analisis data dalam penelitian ini memakai sistem komputerisasi dengan menggunakan perangkat lunak statistik yang meliputi univariat dan bivariat. Penelitian ini dilaksanakan di Instalasi Rawat Inap Rumah Sakit Umum Daerah 45 Kuningan.Waktu Penelitian Oktober 2018 - Agustus 2019.

Hasil

Tabel 1.1 Distribusi frekuensi Umur Penderita Kanker Payudara di RSUD 45 Kuningan Periode Tahun 2018-2019

\begin{tabular}{cccc}
\hline No. & Umur & Frekuensi & $\begin{array}{c}\text { Presentase } \\
(\boldsymbol{\%})\end{array}$ \\
\hline 1. & $>$ 50 Tahun & 9 & 30 \\
2. & $<50$ Tahun & 21 & 70 \\
\hline & Total & $\mathbf{3 0}$ & $\mathbf{1 0 0}$
\end{tabular}

Berdasarkan tabel 1.1 diketahui bahwa dari 30 responden, sebagian besar ibu berumur < 50 tahun yaitu sebanyak 21 orang atau (70\%).

Tabel 1.2 Distribusi frekuensi Pendidikan Penderita Kanker Payudara di RSUD 45 Kuningan Periode Tahun 2018-2019

\begin{tabular}{cccc}
\hline No. & Pendidikan & Frekuensi & $\begin{array}{c}\text { Presentase } \\
(\mathbf{\%})\end{array}$ \\
\hline 1. & SD & 13 & 43,3 \\
2. & SMP & 13 & 43,3 \\
3. & SMA & 4 & 13,3 \\
\hline & Total & $\mathbf{3 0}$ & $\mathbf{1 0 0}$ \\
\hline
\end{tabular}


JURNAL ILMU KESEHATAN BHAKTI HUSADA:

HEALTH SCIENCES JOURNAL, VOL. 11 NO. 01, JUNI 2020

DOI: 10.34305/jikbh.v11i1.140

Berdasarkan tabel 1.2 diketahui bahwa dari 30 responden, sebagian besar ibu berpendidikan SD \& SMP yaitu sebanyak (43,3\%).

Tabel 1.3 Distribusi frekuensi Riwayat Keluarga Penderita Kanker Payudara di RSUD 45 Kuningan Periode Tahun 2018-2019

\begin{tabular}{cccc}
\hline No. & Riwayat Keluarga & Frekuensi & $\begin{array}{c}\text { Presentase } \\
(\boldsymbol{\%})\end{array}$ \\
\hline 1. & Iya & 1 & 3,3 \\
2. & Tidak & 29 & 96,7 \\
\hline & Total & $\mathbf{3 0}$ & $\mathbf{1 0 0}$ \\
\hline
\end{tabular}

Berdasarkan tabel 1.3 dapat diketahui bahwa dari 30 responden, sebagian besar ibu tidak memiliki riwayat kanker payudara pada keluarga yaitu sebanyak 29 orang atau $(96,7 \%)$.

Tabel 1.4 Distribusi frekuensi Kejadian Kanker Payudara di RSUD 45 Kuningan Periode Tahun 2018-2019

\begin{tabular}{cccc}
\hline No. & Kanker Payudara & Frekuensi & $\begin{array}{c}\text { Presentase } \\
(\boldsymbol{\%})\end{array}$ \\
\hline 1. & Stadium awal & 23 & 76,7 \\
2. & Stadium lanjut & 7 & 23,3 \\
\hline & Total & $\mathbf{3 0}$ & $\mathbf{1 0 0}$
\end{tabular}

Berdasarkan tabel 1.4 dapat diketahui bahwa dari 30 responden, sebagian besar ibu memiliki kanker payudara stadium awal yaitu sebanyak 23 orang atau $(76,7 \%)$.

Tabel 1.5 Hubungan Kejadian Penderita Kanker Payudara Berdasarkan Umur ibu di RSUD 45 Kuningan Periode Tahun 2018-2019

\begin{tabular}{|c|c|c|c|c|c|c|c|c|}
\hline \multirow{3}{*}{ No. } & \multirow{3}{*}{ Umur } & \multicolumn{4}{|c|}{ Kanker Payudara } & \multirow{2}{*}{\multicolumn{2}{|c|}{ Total }} & \multirow{3}{*}{$\begin{array}{c}\mathrm{P} \\
\text { value }\end{array}$} \\
\hline & & \multicolumn{2}{|c|}{$\begin{array}{l}\text { Stadium } \\
\text { awal }\end{array}$} & \multicolumn{2}{|c|}{$\begin{array}{c}\text { Stadium } \\
\text { lanjut }\end{array}$} & & & \\
\hline & & $\mathrm{F}$ & $\%$ & $\mathrm{~F}$ & $\%$ & $\mathrm{~F}$ & $\%$ & \\
\hline \multirow[t]{2}{*}{1.} & $>50$ tahun & 3 & 33,3 & 6 & 66,7 & 9 & 10 & \multirow{4}{*}{0,001} \\
\hline & & & & & & & 0 & \\
\hline \multirow[t]{2}{*}{2.} & $<50$ tahun & 20 & 95,2 & 1 & 4,8 & 21 & 10 & \\
\hline & & & & & & & 0 & \\
\hline
\end{tabular}
nilai $p<0,05$ dengan demikian ada hubungan antara umur dengan kejadian kanker payudara. 
JURNAL ILMU KESEHATAN BHAKTI HUSADA:

HEALTH SCIENCES JOURNAL, VOL. 11 NO. 01, JUNI 2020

DOI: $10.34305 /$ jikbh.v11i1.140
Ciptaan disebarluaskan di bawah

Lisensi Creative Commons Atribusi-

NonKomersial-BerbagiSerupa 4.0

Internasional

Tabel 1.6 Hubungan Kejadian Penderita Kanker Payudara Berdasarkan

Pendidikan ibu di RSUD 45 Kuningan Periode Tahun 2016-2019

\begin{tabular}{|c|c|c|c|c|c|c|c|c|}
\hline \multirow{3}{*}{ No. } & \multirow{3}{*}{ Pendidikan } & \multicolumn{6}{|c|}{ Kanker Payudara } & \multirow{3}{*}{$P$ value } \\
\hline & & \multicolumn{2}{|c|}{ Stadium awal } & \multicolumn{2}{|c|}{$\begin{array}{c}\text { Stadium } \\
\text { lanjut }\end{array}$} & \multicolumn{2}{|c|}{ Total } & \\
\hline & & $\mathrm{F}$ & $\%$ & $\mathrm{~F}$ & $\%$ & $\mathrm{~F}$ & $\%$ & \\
\hline 1. & $\mathrm{SD}$ & 7 & 53,8 & 6 & 46,2 & 13 & 100 & \multirow{3}{*}{0,034} \\
\hline 2. & SMP & 12 & 92,3 & 1 & 7,7 & 13 & 100 & \\
\hline 3. & SMA & 4 & 17,4 & 0 & 0 & 4 & 100 & \\
\hline
\end{tabular}

Dari hasil uji statistik dengan menggunakan uji Chi Square dengan p-value yaitu 0,034 jadi nilai $p<0,05$ dengan demikian ada hubungan antara pendidikan dengan kejadian kanker payudara.

Tabel 1.7 Hubungan Kejadian Penderita Kanker Payudara Berdasarkan Riwayat Keluarga ibu di RSUD 45 Kuningan Periode Tahun 2018-2019

\begin{tabular}{|c|c|c|c|c|c|c|c|c|}
\hline \multirow{3}{*}{ No. } & \multirow{3}{*}{$\begin{array}{l}\text { Riwayat } \\
\text { Keluarga }\end{array}$} & \multicolumn{4}{|c|}{ Kanker Payudara } & \multirow{2}{*}{\multicolumn{2}{|c|}{ Total }} & \multirow{3}{*}{$P$ value } \\
\hline & & \multicolumn{2}{|c|}{ Stadium awal } & \multicolumn{2}{|c|}{ Stadium lanjut } & & & \\
\hline & & $\mathrm{F}$ & $\%$ & $\mathrm{~F}$ & $\%$ & $\mathrm{~F}$ & $\%$ & \\
\hline 1. & Iya & 1 & 100 & 0 & 0 & 1 & 100 & 0,767 \\
\hline 2. & Tidak & 22 & 75,9 & 7 & 24,1 & 29 & 100 & \\
\hline
\end{tabular}

Dari hasil uji statistik dengan menggunakan uji Chi Square dengan p-value yaitu 0,767 jadi nilai $p>0,05$ dengan demikian tidak ada hubungan antara riwayat keluarga dengan kejadian kanker payudara.

\section{Pembahasan}

Berdasarkan hasil penelitian dapat diketahui bahwa dari 30 responden, sebagian besar ibu berumur $<50$ tahun yaitu sebanyak 21 orang atau (70\%).Perempuan berusia pertengahan 30 tahun sampai pertengahan 40 tahun memiliki resiko terkena kanker payudara dengan peningkatan tertinggi. Usia paling umum terdeteksinya tahap-tahap pertama kanker payudara adalah lima tahun atau lebih sebelum menopause. Peningkatan kejadian kanker payudara pada usia $<50$ tahun (pramenopause) dapat dipengaruhi oleh faktor pendidikan, umur, riwayat keluarga dan juga pola hidup yang tidak baik atau tingkat stress dan masih banyak faktor risiko yang lainnya. Sedangkan peningkatan pada usia $>50$ tahun (menopause) dikarenakan penurunan fungsi-fungsi organ dan menurunnya daya tahan tubuh. Lemak dan jaringan payudara 
JURNAL ILMU KESEHATAN BHAKTI HUSADA:

HEALTH SCIENCES JOURNAL, VOL. 11 NO. 01, JUNI 2020 DOI: 10.34305/jikbh.v11i1.140

dapat bertambah berbahaya pada saat usia

60 tahun dibanding usia 20 tahun, karena pada usia tersebut telah banyak akumulasi racun yang terkumpul di dalam jaringanjaringan lemak payudara (Hidayat, 2016). Berdasarkan penelitian dapat diketahui bahwa dari 30 responden, sebagian besar ibu berpendidikan SD \& SMP yaitu sebanyak $(43,3 \%)$.

Kanker payudara dapat diderita oleh semua tingkatan pendidikan dari hasil penelitian, responden yang memiliki pendidikan rendah dan tinggi sama-sama menderita kanker payudara. Disimpulkan bahwa terserang penyakit kanker payudara tidak dapat dibedakan oleh tingkatan pendidikan, baik yang berpendidikan tinggi maupun berpendidikan rendah. Pendidikan merupakan sebuah faktor yang dapat mempengaruhi seseorang dalam berperilaku, pendidikan juga dapat mendewasakan seseorang untuk berperilaku dengan baik, sehingga dapat menjadi dasar dalam membuat dan mengambil keputusan yang tepat (Notoatmodjo, 2010).

Berdasarkan penelitian dapat diketahui bahwa dari 30 responden sebagian besar ibu tidak memiliki riwayat kanker payudara pada keluarga yaitu sebanyak 29 orang atau $(96,7 \%)$.

Hanya sekitar $10 \%$ kanker payudara di beberapa negara industri di barat disebabkan oleh mutasi genetis yang
Ciptaan disebarluaskan di bawah

Lisensi Creative Commons Atribusi-

NonKomersial-BerbagiSerupa 4.0

Internasional.

bersifat

keturunan.

Mutasi-m

cenderung diturunkan dari pihak ayah maupun ibu (yang mengidap penyakit tersebut maupun tidak). Pada umumnya, perempuan yang memiliki kecenderungan genetis terkena kanker payudara akan mengidap penyakit tersebut sebelum usia 50 tahun. Mereka yang memiliki anggota keluarga penderita kanker payudara sebelum usia 65 tahun, memiliki resiko dua kali lipat. Semakin muda anggota keluarga mereka saat terkena kanker payudara, maka semakin besar kemungkinan penyakit tersebut bersifat keturunan. Apabila dua anggota keluarga terkena kanker payudara, resiko terkena penyakit tersebut menjadi empat sampai enam kali lipat lebih tinggi (Hidayat, 2016). Hal ini sejalan dengan hasil penelitian Trisnadewi, (2013), hasil penelitian ini menunjukkan bahwa dalam analisis bivariat, faktor riwayat keluarga dengan kanker payudara pada wanita di RSUP Sanglah Denpasar meningkatkan risiko kejadian kanker payudara dengan nilai $\mathrm{OR}=8(95 \% \mathrm{CI}: 1,839-34,794)$. Ditemukannya beberapa anggota dalam satu keluarga yang menderita penyakit keganasan memberi petunjuk bahwa kanker payudara merupakan penyakit familial.

Berdasarkan hasil penelitian dapat diketahui bahwa dari 9 responden yang berumur $>50$ tahun sebagian besar yaitu sebanyak (66,7\%) mengalami kanker payudara stadium lanjut, sedangkan dari 21 E-ISSN 2623-1204 P-ISSN 2252-9462 |67 
JURNAL ILMU KESEHATAN BHAKTI HUSADA:

HEALTH SCIENCES JOURNAL, VOL. 11 NO. 01, JUNI 2020 DOI: $10.34305 / j i k b h . v 11 i 1.140$

responden yang berumur $<50$ tahun sebagian besar yaitu sebanyak $(95,2 \%)$ mengalami kanker payudara stadium awal. Dari hasil uji statistik dengan menggunakan uji Chi Square dengan $p$-value yaitu 0,001 jadi nilai $p<0,05$ dengan demikian ada hubungan antara umur dengan kejadian kanker payudara.

Berdasarkan teori, perempuan yang berusia pertengahan 30 tahun sampai pertengahan 40 tahun memiliki resiko terkena kanker payudara dengan peningkatan tertinggi. Pada wanita yang mengalami menopause terlambat, setelah umur 55 tahun dapat meningkatkan risiko terkena kanker payudara mencapai puncaknya pada usia lebih dari 60 tahun (Mulyani, 2013). Hal ini sejalan dengan hasil penelitian Rianti et al., (2012) tentang hubungan umur dengan kejadian kanker payudara. Hasil penelitian sebagian ibu yang berumur $<50$ tahun beresiko 3,52 kali lebih tinggi untuk tidak menderita kanker payudara dibandingkan dengan ibu yang berumur $>50$ tahun beresiko 6,5 kali lebih tinggi menderita kanker payudara. Berdasarkan hasil penelitian Pada ibu yang memiliki umur > 50 tahun (menopause) beresiko lebih tinggi menderita kanker payudara stadium lanjut, dan ibu yang memiliki umur $<50$ tahun memiliki resiko lebih tinggi menderita kanker payudara stadium awal.
Ciptaan disebarluaskan di bawah

Lisensi Creative Commons Atribusi-

NonKomersial-BerbagiSerupa 4.0

Internasional.

Hubungan Pendidikan dengan

Kejadian Kanker Payudara di RSUD 45 Kuningan Periode Tahun 2016-2017

Berdasarkan penelitian dapat diketahui bahwa dari 13 responden yang berpendidikan SD sebagian besar yaitu sebanyak (53,8\%) mengalami kanker payudara stadium awal. Dari 13 responden yang berpendidikan SMP sebagian besar yaitu sebanyak $(92,3 \%)$ mengalami kanker payudara stadium awal. Sedangkan dari 4 responden yang berpendidikan SMA sebagian besar yaitu sebanyak $(17,4 \%)$ mengalami kanker payudara stadium awal. Dari hasil uji statistik dengan menggunakan uji Chi Square dengan p-value yaitu 0,034 jadi nilai $p<0,05$ dengan demikian ada hubungan antara pendidikan dengan kejadian kanker payudara. Kanker payudara dapat diderita oleh semua tingkatan pendidikan dari hasil penelitian, responden yang memiliki pendidikan rendah dan tinggi sama-sama menderita kanker payudara. Disimpulkan bahwa terserang penyakit kanker payudara tidak dapat dibedakan oleh tingkatan pendidikan, baik yang berpendidikan tinggi maupun berpendidikan rendah. Hal ini sejalan dengan hasil penelitian AS, (2010) bahwa berdasarkan dari uji chi square hubungan antara pendidikan terhadap kajian kanker payudara didapatkan adanya hubungan antara pendidikan terhadap kejadian kanker payudara dengan nilai signifikansi $p=$ E-ISSN 2623-1204 P-ISSN 2252-9462 | 68 
JURNAL ILMU KESEHATAN BHAKTI HUSADA:

HEALTH SCIENCES JOURNAL, VOL. 11 No. 01, JUNI 2020 DOI: $10.34305 / j i k b h . v 11 i 1.140$

0,019 dimana nilai $p<0,05$ sehingga $\mathrm{H}_{\mathrm{o}}$ ditolak dan $\mathrm{H}_{\mathrm{a}}$ diterima yang berarti bahwa hubungan antara pendidikan terhadap kejadian kanker payudara cukup kuat.

Hubungan Riwayat Keluarga dengan Kejadian Kanker Payudara di RSUD 45 Kuningan Periode Tahun 20162017

Berdasarkan penelitian dapat diketahui bahwa dari 1 responden yang memiliki riwayat keluarga sebagian besar yaitu sebanyak (100\%) mengalami kanker payudara stadium awal, sedangkan dari 29 responden yang tidak memiliki riwayat keluarga sebagian besar yaitu sebanyak (75,9\%) mengalami kanker payudara stadium awal. Dari hasil uji statistik dengan menggunakan uji Chi Square dengan $p$ value yaitu 0,767 jadi nilai $p>0,05$ dengan demikian tidak ada hubungan antara riwayat keluarga dengan kejadian kanker payudara.

Hal ini tidak sejalan dengan hasil penelitian Karima \& Wahyono, (2013) untuk tingkat keluarga yang menderita kanker payudara dibandingkan wanita yang tidak memiliki riwayat keturunan kanker payudara, wanita yang memiliki tingkat keturunan kanker payudara pada keluarga tingkat 2 atau 3 berisiko 2,544 kali lebih tinggi (95\% CI: 0,854-7,580) untuk terkena kanker payudara hubungan ini tidak bermakna secara statistik karena $p$ value sebesar 0,094 (>0,05). Wanita yang
Ciptaan disebarluaskan di bawah

Lisensi Creative Commons Atribusi-

NonKomersial-BerbagiSerupa 4.0

Internasional.

memiliki riwayat keturunan kanker payudara pada keluarga tingkat 1 berisiko 3,854 kali (95\% CI: 1,031-14,411) untuk terkena kanker payudara. Hubungan ini bermakna secara statistik karena $p$ value sebesar 0,045 $(<0,05)$.

Hal ini sependapat dengan Mulyani, (2013). Jika ibu saudara perempuan, adik, kakak, memiliki kanker payudara (terutama sebelum usia 40 tahun), resiko terkena kanker payudara lebih tinggi. Risiko dapat berlipat ganda jika ada lebih dari satu anggota keluarga inti yang terkena kanker payudara dan semakin muda ada anggota keluarga yang terkena kanker maka akan semakin besar penyakit tersebut bersifat keturunan.

\section{Daftar Pustaka}

AS, S. Y. (2010). Faktor-Faktor Yang Berhubungan dengan Kejadian Kanker Payudara di RSUP DR. Wahidin Sudirohusodo Makassar. Univeritas Islam Negeri Alauddin Makassar.

Hidayat, A. (2016). Hubungan Antara Religiusitas Dengan Kualitas Hidup Pasien Kanker Payudara Dipoli Bedah Rsud Panembahan Senopati Bantul. STIKES Jenderal A. Yani Yogyakarta.

Infodatin Kemenkes, R. I. (2015). Pusat

Data dan Informasi Kementrian 
JURNAL ILMU KESEHATAN BHAKTI HUSADA:

HEALTH SCIENCES JOURNAL, VOL. 11 NO. 01, JUNI 2020 DOI: 10.34305/jikbh.v11i1.140

Kesehatan Republik Indonesia. Jakarta.

Karima, U. Q., \& Wahyono, T. Y. (2013). Faktor-faktor yang Berhubungan dengan Kejadian Kanker Payudara Wanita di Rumah Sakit Umum Pusat Nasional (RSUPN) dr. Cipto Mangunkusumo Jakarta Tahun 2013. Cipto Mangunkusumo Jakarta Tahun.

Kesehatan, B. P. dan P., \& RI, K. K. (2013). Penyajian Pokok-Pokok Hasil Riset Kesehatan Dasar 2013. http://kesga.kemkes.go.id/images/ped oman/Data Riskesdas 2013.pdf Mulyani, N. S. (2013). Kanker Payudara dan PMS pada kehamilan.
Ciptaan disebarluaskan di bawah Lisensi Creative Commons AtribusiNonKomersial-BerbagiSerupa 4.0

Internasional.

Notoatmodjo, S. (2010). Metododologi Penelitian Kesehatan.

Rianti, E., Tirtawati, G. A., \& Novita, H. (2012). Faktor-faktor yang berhubungan dengan risiko kanker payudara wanita. J Health Quality.

Society, A. C. (2017). Breast Cancer Facts $\&$ Figures 2017-2018. https://www.cancer.org/research/canc er-facts-statistics/breast-cancer-factsfigures.html

Trisnadewi, N. W. (2013). Faktor risiko kanker payudara pada wanita di RSUP Sanglah Denpasar. Public Health and Preventive Medicine Archive, 1(2). 